\title{
Thyroid hormone, thyroid hormone receptors, and cancer: a clinical perspective
}

\author{
Lars C Moeller and Dagmar Führer
}

Division of Laboratory Research, Department of Endocrinology and Metabolic Diseases, University of DuisburgEssen, Hufelandstraße 55, 45127 Essen, Germany

Correspondence

should be addressed to

L C Moeller

Email

lars.moeller@uni-due.de

\begin{abstract}
Thyroid hormones (THs) may play a role in diseases other than hyper- and hypothyroidism. Several lines of evidence suggest tumor-promoting effects of $\mathrm{TH}$ and $\mathrm{TH}$ receptors. They are possibly mediated by phosphatidylinositol-3-kinase and MAPK and involve among others stimulation of angiogenesis via $\alpha \mathrm{v} \beta 3$. Thus, an increased risk for colon, lung, prostate, and breast cancer with lower TSH has been demonstrated in epidemiological studies, even suggesting a TH dose effect on cancer occurrence. Furthermore, higher TH levels were associated with an advanced clinical stage of breast and prostate cancer. In rodent models, TH stimulated growth and metastasis of tumor transplants, whereas hypothyroidism had opposite effects. In clinical studies of glioblastoma and head and neck cancer, hypothyroid patients showed longer survival than euthyroid patients. Also, patients with renal cell cancer that were treated with the tyrosine kinase inhibitor sunitinib and developed hypothyroidism in due course showed significantly longer survival than patients that remained euthyroid. Development of hypothyroidism was an independent predictor for survival in two studies. Yet, it is still possible that hypothyroidism is only a surrogate marker for treatment efficacy and does not positively influence treatment outcome by itself. Future cancer treatment studies, especially with substances that can induce hypothyroidism, should therefore be designed in a way that allows for an analysis of thyroid function status and its contribution on treatment outcome.
\end{abstract}
Key Words
- thyroxine
- PI3K
- $\alpha \mathrm{v} \beta 3$
tyrosine kinase inhibitor

\section{Introduction}

The thyroid hormones (THs) thyroxine $\left(\mathrm{T}_{4}\right)$ and triiodothyronine $\left(\mathrm{T}_{3}\right)$ are mostly recognized for their roles in normal growth, development, and metabolism, especially during fetal development and early childhood. In adults, the diseases usually associated with $\mathrm{TH}$ are excess and lack of TH and hyper- and hypothyroidism, with their distinct clinical symptoms. But TH may play a greater role in the development and course of diseases. This perspective focuses on evidence for tumor-promoting or suppressing effects of $\mathrm{TH}$ and their receptors and potential clinical consequences.

\section{TH receptors and actions}

TH action is mainly understood as modification of gene expression, mediated by the nuclear TH receptors (TRs). Two different genes, THRA on chromosome 17 and THRB on chromosome 3 , encode TR $\alpha$ and TR $\beta$ respectively (Yen 2001). They share a highly homologous protein structure including a central DNA binding domain (DBD) and a C-terminal ligand binding domain (LBD). A short amino acid sequence within the DBD mediates TR binding to

Published by Bioscientifica Ltd. 
DNA and dictates sequence specificity. With the DBD, the TRs recognize TH response elements (TREs) in the promoter of their target genes that act as enhancers for genes positively regulated by TH. The LBD binds TH, $\mathrm{T}_{3}$ with 10- to 15 -fold higher affinity than $\mathrm{T}_{4}$. Due to alternative splicing and promoter usage, various TR isoforms exist. The most studied isoforms are TR $\beta 1$ and TR $\beta 2$, which differ in the amino terminal domain, and $\mathrm{TR} \alpha 1$ and TR $\alpha 2$, which differ in the C-terminal region in length and amino sequence. As a consequence, TR $\alpha 2$ lacks $\mathrm{T}_{3}$ binding activity and acts as a weak antagonist in vitro. The TR $\alpha 1,-\beta 1$, and $-\beta 2$ isoforms bind DNA and $\mathrm{T}_{3}$ and act as functional apo- and liganded TRs. In addition, truncated TR isoforms exist that lack amino terminal domains and DNA binding (Cheng et al. 2010).

\section{Classical TH and TR action}

In the classical model of gene induction by $\mathrm{TH}$, the TRs bind to TREs in the promoter of target genes. Without $T_{3}$, corepressors with histone deacetylase activity are bound to the TR complex, preventing transcription. Upon $\mathrm{T}_{3}$ binding, corepressors are released and replaced by coactivators, which ultimately engages the RNA polymerase II in transcription of the target gene. The TRs are therefore seen as ligand-dependent transcription factors. Studies from TR knockout mice and stably transformed HepG2 cells showed largely overlapping gene expression patterns of positively regulated genes for $\mathrm{TR} \alpha$ and $\mathrm{TR} \beta$, suggesting that TR amount, rather than isoform type, is important (Yen et al. 2003). Yet, the TR isoforms show differential DNA binding affinity to promoters and the transcriptional response of a gene on a given tissue may depend on the predominant TR isoform (Chan \& Privalsky 2009, Chiamolera et al. 2012). The clinical differences between patients with resistance to TH (RTH) due to TR $\beta$ and TR $\alpha$ mutations further demonstrate that distinct physiological roles for the TR isoforms exist (Refetoff \& Dumitrescu 2007, Bochukova et al. 2012, Ferrara et al. 2012, van Mullem et al. 2012).

\section{Nonclassical TH and TR action}

A few years ago, it became evident that TH and TR $\beta$ could also act through a different mechanism: the ligand-bound TR $\beta$ could activate the phosphatidylinositol-3-kinase (PI3K) pathway via phosphorylation of Akt/PKB within minutes, which subsequently affected gene expression (Simoncini et al. 2000, Lei et al. 2004, Cao et al. 2005). This mechanism is independent of TR $\beta$ binding to DNA and
TREs. Ultimately, this nonclassical action of TH results in induction of gene expression. For example, ZAKI- $4 \alpha$ had previously been described as a TH-responsive gene. ZAKI- $4 \alpha$ induction by $\mathrm{T}_{3}$ is dependent on TR $\beta$ and could be blocked by PI3K inhibitors, such as LY294002 (Cao et al. 2005, Moeller et al. 2005b). Similar results as for TR $\beta$ were obtained for TR $\alpha$. Cao et al. (2009) could demonstrate PI3K activation in TR $\alpha$ overexpressing neuronal cells and Hiroi et al. (2006) found TR $\alpha 1$ association with p85 $\alpha$ followed by phosphorylation of Akt/PKB, a downstream target of PI3K, and activation of endothelial nitric oxide synthase.

\section{$\alpha v \beta 3$ as TR}

Bergh et al. (2005) demonstrated that $\mathrm{T}_{4}$ and $\mathrm{T}_{3}$ could bind to a purified plasma membrane protein, the integrin $\alpha \mathrm{v} \beta 3$. av $\beta 3$ contains two TH binding sites, denoted as S1 and S2, which translate the TH signal differently (Davis et al. 2011, Freindorf et al. 2012). S1 exclusively binds $T_{3}$ at physiological concentrations and leads to PI3K activation. S2 binds $\mathrm{T}_{4}$, and to a lesser extent $\mathrm{T}_{3}$, and ultimately activates the ERK1/2 pathway (Lin et al. 2009). As the integrin $\alpha \mathrm{v} \beta 3$ binds $\mathrm{TH}$ and transmits $\mathrm{TH}$ the signal into the cell, it clearly qualifies as a cell surface TR.

These various ways of action of $\mathrm{TH}$ and their receptors harbor potential to promote tumor growth. For example, the most highly induced genes in a microarray study of $\mathrm{T}_{3}$-induced gene expression in human skin fibroblasts were the aldo-keto reductases 1-3 (AKR1C1-3; Moeller et al. 2005b), which are associated with aggressiveness of prostate cancer due to increased conversion of adrenal androgens to testosterone (Fung 2006, Penning \& Byrns 2009). And the oncogenic PI3K pathway, activated by TH via $T R \alpha / \beta$ and the $S 1$ site of $\alpha v \beta 3$, facilitates cell growth and survival and inhibits apoptosis (Chalhoub \& Baker 2009). Via PI3K, $T_{3}$ induces expression of the $\alpha$ subunit of the transcription factor hypoxia-inducible factor 1 (HIF1; Moeller et al. 2005a). HIF1 target genes play key roles in cancer biology, from angiogenesis to adaptation to hypoxia, prevalent in rapidly growing tumors, and invasion and metastasis (Semenza 2009). HIF1 $\alpha$ expression is a prognostic marker in renal cell carcinoma (RCC) and breast and prostate cancer, among others (Kimbro \& Simons 2006). TH can, via $\alpha v \beta 3 / S 2$, activate ERK1/2 and induce fibroblast growth factor 2 and promote angiogenesis, also crucial for rapid tumor growth (Davis 2004).

From a clinical perspective, the following important questions regarding $\mathrm{TH}$ and cancer arise: can $\mathrm{TH}$ influence tumor incidence, tumor progress and metastasis, and, ultimately, success of tumor treatment?

Published by Bioscientifica Ltd 


\section{Epidemiology suggests tumor-promoting effects of $\mathrm{TH}$}

A population-based case-control study of risk factors for ovarian cancer with 767 cancer patients and 1367 controls found a higher rate of patients with a history of hyperthyroidism in the cancer patients than in the controls. The odds ratio (OR) for ovarian cancer was almost doubled in participants with a history of hyperthyroidism (OR 1.8, adjusted for age, pregnancies, race, oral contraceptive use, hysterectomy, and familial history of ovarian cancer) (Ness et al. 2000). In a similar study on risks for pancreatic cancer, a history of hyperthyroidism was associated with a twofold increased risk (OR 2.1, adjusted for race, education, BMI, smoking, and history of diabetes) (Ko et al. 2007). While these retrospective studies indicated an increased cancer risk with higher TH levels, their results depended on selfreported thyroid disorders and thyroid function tests were not analyzed.

A relationship also appears to exist between $\mathrm{TH}$ and prostate cancer: $T_{3}$ levels were measured and compared in 161 men with localized prostate cancer, 20 men with benign prostate hyperplasia (BPH), and 27 age-matched controls with no history of cancer, $\mathrm{BPH}$, or thyroid disease (Lehrer et al. 2002). Patients with prostate cancer and BPH had significantly higher $\mathrm{T}_{3}$ levels than controls. Furthermore, $\mathrm{T}_{3}$ levels were associated with higher clinical stage and risk of recurrence of prostate cancer (Lehrer et al. 2001). At diagnosis, 68 prostate cancer patients were divided into three risk groups for recurrence, low risk (serum PSA $<10$, stage $\leq \mathrm{T} 2 \mathrm{a}$, or Gleason grade $\leq 6$ ), moderate risk (serum PSA $10-15$, stage $\leq \mathrm{T} 2 \mathrm{~b}$, or Gleason grade 7), and high risk (serum PSA $>15$, stage $\mathrm{T} 2 \mathrm{c}$ or $\mathrm{T}_{3}$, or Gleason grade $>7$ ). While all patients had $\mathrm{T}_{3}$ levels within the reference range, $T_{3}$ levels were highest in the high-risk group and significantly different from the low- and moderate-risk groups. More recently, a prospective, randomized, and control-matched study on THs and prostate cancer risk in smokers showed that hypothyroid men had a lower risk of prostate cancer than euthyroid men $(\mathrm{OR}=0.48, P=0.006)$ (Mondul et al. 2012).

Cristofanilli et al. (2005) retrospectively studied the prevalence of hypothyroidism in patients with breast cancer. They identified 74 hypothyroid women in 884 breast cancer patients. Compared with euthyroid patients, the hypothyroid patients were older at diagnosis (58.8 vs 51.1 years, $P<0.001)$ and were more likely to be diagnosed at an earlier stage of breast cancer (pathologic stage I/II: 95 vs $85.9 \%, P=0.025)$, with a smaller tumor $(\mathrm{T} 1(\leq 2 \mathrm{~cm})$ :
72.5 vs $55 \%, P=0.002$ ) and without pathologic lymph node involvement (63.9 vs $55.9 \%$, not significant). These results seem to indicate that invasive breast cancer progression may be slower in hypothyroidism. In interpreting these results, it must be considered that hypothyroidism was determined by the use of thyroid supplements as TSH and free $\mathrm{T}_{4}$ levels were not available. TH levels have probably been normal since start of $\mathrm{T}_{4}$. Hypothyroidism in this study therefore refers to a period of assumedly low TH levels of unknown duration in the patients' past.

Also for breast cancer, a prospective study of 2696 women showed an association between $\mathrm{T}_{3}$ levels at baseline and cancer risk during a mean follow-up of 19.3 years (Tosovic et al. 2010). The overall risk of breast cancer was statistically significantly higher for women with $T_{3}$ in the highest vs lowest quartile. This association was due to findings in the 1322 peri-/postmenopausal women because the association was even stronger in these participants, but absent in pre-menopausal women. There were three cases of breast cancer in the 196 women with a $T_{3}$ in the lowest quartile and 38 cases in the 408 women with a $T_{3}$ in the highest quartile. From lowest to highest $T_{3}$ quartile, the adjusted relative risk continuously increased from 1.00 to $3.26,5.53$, and 6.87 respectively. This increase was preserved when taking into account only tumors diagnosed 3 years after baseline. These results indicate a positive correlation and a dose response for $\mathrm{T}_{3}$ and risk of breast cancer development in peri-/postmenopausal women.

Another prospective study assessed a connection of thyroid function with cancer risk: participants of the Nord-Trøndelag Health Study were studied for TH and TSH levels and cancer incidence (Hellevik et al. 2009). After exclusion of participants with a history of thyroid disease, a history of cancer or missing information, almost 30.000 participants, could be analyzed for cancer risk (29.691 people, 19.710 women, and 9.981 men) in a median follow-up of 9 years using the Cancer Registry of Norway. According to their TSH, the participants were placed in five categories: each one below and above the TSH reference ranges, indicating hyper- and hypothyroidism respectively and three groups within the TSH reference range. Participants with a TSH in the lower normal third were used as the reference group with a hazard ratio (HR) for cancer of 1.0 by definition. Total cancer risk for participants with a TSH below the reference range was higher than for people from any other category and 34\% increased compared with the reference group (HR 1.34; adjusted for age, sex, and smoking status). This increased cancer risk was mainly due to an increased risk for colon

Published by Bioscientifica Ltd. 
cancer (HR 1.38), prostate cancer (HR 1.97), lung cancer (HR 2.34), and breast cancer (HR 1.20). When HRs were calculated only for cancers diagnosed 2 years and later after baseline, to exclude effects of yet undiscovered cancer on TH and TSH levels, these results were only strengthened. Interestingly, a subanalysis of the participants with a TSH below the reference range revealed that during follow-up starting 2 years after baseline, the HR for total cancer for participants with suppressed TSH and elevated free $\mathrm{T}_{4}$ or total $\mathrm{T}_{3}$ was higher (HR 2.35) than for those with either suppressed TSH and normal free $\mathrm{T}_{4}$ and total $\mathrm{T}_{3}$ levels or TSH between 0.2 and $0.49 \mathrm{mU} / \mathrm{l}$ (HR 1.42), again suggesting a dose effect for $\mathrm{TH}$ on cancer occurrence.

Different results were obtained in a case-control study for hepatocellular carcinoma (HCC). Women, but not men, with a history of hypothyroidism had a 2.8 -fold higher risk of HCC than participants without a history of hypothyroidism (after adjustment for age, race, diabetes, smoking, alcohol consumption, family history of cancer, and HBV/HCV status) (Hassan et al. 2009). This calculation was based on self-reported absence or presence of hypothyroidism because $\mathrm{TH}$ levels and data regarding substitution were not available. In this context, it is interesting that hypothyroidism was significantly more prevalent in patients with HCC of unknown etiology than in HCC patients with alcoholic liver disease or HCV in another case-control study (Reddy et al. 2007), suggesting that hypothyroidism may be a permissive factor in the development of HCC.

\section{TH, TRs, and tumor progress in animal models}

An experimental method for demonstrating that $\mathrm{TH}$ are involved in tumor growth has been the xenograft assay, which involves s.c. implantation of tumor cells into immunodeficient mice with subsequent treatment, e.g. TH treatment or induction of hypothyroidism, and measurements of tumor growth rates and extent of metastasis.

\section{TH effects in rodent tumor implant models}

Evidence for tumor-promoting effects of $\mathrm{TH}$ stems from mouse models of cancer cell lines (Table 1). Shoemaker et al. (1976) reported a connection between survival and induced hypothyroidism in mice after implantation of murine mammary adenocarcinoma cells. Half of the mice were treated with propylthiouracil (PTU) for 21 days, starting on day 14 postimplant through day 35 . Tumors had grown in all mice until day 13 and from day 16 on the tumor size was different between the PTU-treated group and the untreated control group with $0.22 \pm 0.2$ and 0.63 $\pm 0.45 \mathrm{~cm}^{3}$ respectively. This difference was maintained throughout the rest of the experiment with mean tumor sizes in the surviving animals of $8.3 \pm 5.1 \mathrm{vs} 17.6 \pm 8.2 \mathrm{~cm}^{3}$

Table 1 Influence of TH on tumor growth and metastasis formation in tumor implant rodent models.

\begin{tabular}{|c|c|c|c|c|c|}
\hline & Tumor implant (cell line) & Tumor origin & Comparison & Observation & Reference \\
\hline 1 & $\begin{array}{l}\text { Mammary adenocarcinoma } \\
\text { (C3HBA) }\end{array}$ & Murine & No treatment vs PTU & $\begin{array}{l}\text { Reduced tumor size and } \\
\text { prolonged survival in the } \\
\text { PTU group }\end{array}$ & $\begin{array}{l}\text { Shoemaker et al. } \\
\text { (1976) }\end{array}$ \\
\hline 2 & $\begin{array}{l}\text { Sarcoma (S1), fibrosarcoma } \\
\text { (T241) }\end{array}$ & Murine & $\begin{array}{l}\text { No treatment vs } \mathrm{T}_{4} \text { treat- } \\
\text { ment vs }{ }^{131} \mathrm{I} \text {-induced } \\
\text { hypothyroidism }\end{array}$ & $\begin{array}{l}\text { Tumor weight and meta- } \\
\text { static index increased in } \\
\text { the } \mathrm{T}_{4} \text { group and reduced } \\
\text { in the hypothyroid group }\end{array}$ & Kumar et al. (1979) \\
\hline 3 & Morris hepatoma 44 & Rat & $\begin{array}{l}\text { No treatment vs } \\
\text { hypothyroidism }\end{array}$ & $\begin{array}{l}\text { Reduced tumor size, lung } \\
\text { metastasis, and prolonged } \\
\text { survival in the hypo- } \\
\text { thyroid groups }\end{array}$ & $\begin{array}{l}\text { Mishkin et al. } \\
\quad(1981)\end{array}$ \\
\hline 4 & $\begin{array}{l}\text { Prostate adenocarcinoma } \\
\quad \text { (PC3) }\end{array}$ & Human & No treatment vs PTU & $\begin{array}{l}\text { Reduced tumor growth in } \\
\text { the PTU group }\end{array}$ & $\begin{array}{l}\text { Theodossiou \& } \\
\text { Schwarzenberger } \\
\text { (2000) }\end{array}$ \\
\hline 5 & $\begin{array}{l}\text { Prostate adenocarcinoma } \\
\text { (PC3), lung adenocarci- } \\
\text { noma (201T) }\end{array}$ & Human & $\begin{array}{l}\text { No treatment vs PTU- } \\
\text { induced hypothyroidism }\end{array}$ & $\begin{array}{l}\text { Reduced tumor growth in } \\
\text { the PTU group }\end{array}$ & $\begin{array}{l}\text { Theodossiou et al. } \\
\text { (1999) }\end{array}$ \\
\hline 6 & $\begin{array}{l}\text { Hepatocarcinoma (SK-hep1), } \\
\text { breast cancer (MDA) }\end{array}$ & Human & $\begin{array}{l}\text { No treatment vs } \\
\text { methimazole-induced } \\
\text { hypothyroidism }\end{array}$ & $\begin{array}{l}\text { Reduced tumor growth } \\
\text { and proliferation, but } \\
\text { enhanced invasiveness } \\
\text { and metastasis in } \\
\text { hypothyroid mice }\end{array}$ & $\begin{array}{l}\text { Martinez-Iglesias } \\
\text { et al. (2009) }\end{array}$ \\
\hline
\end{tabular}

PTU, propylthiouracil.

http://erc.endocrinology-journals.org DOI: 10.1530/ERC-12-0219
(C) 2013 Society for Endocrinology Printed in Great Britain
Published by Bioscientifica Ltd 
(PTU treated vs control) on day 48 . The delay in tumor growth seemed to be reflected in survival time with the PTU-treated animals surviving $58.9 \pm 24.7$ vs 42.7 \pm 10.4 days of the control mice. However, the extent of hypothyroidism achieving this effect is unknown as hormone values are not available for this experiment.

In rats, hypothyroidism inhibited both local and metastatic growth of hepatomas and prolonged host survival. Rats, in which hypothyroidism was induced by either PTU or ${ }^{131}$ I treatment or thyroidectomy 2 weeks after hepatoma implantation (Morris hepatoma 44) into the hind limbs, survived longer and developed smaller tumors than untreated controls (Mishkin et al. 1981). The time of induction of hypothyroidism by ${ }^{131}$ I treatment influenced the outcome significantly: while early treatment 2 weeks after implantation led to $78 \%$ longer survival compared with untreated controls, the survival benefit was reduced to $35 \%$ at 6 weeks and $17 \%$ at 11 weeks postimplantation. Similarly, incidence of pulmonary metastasis was reduced from $80 \%$ in untreated controls to 30 and $40 \%$ with ${ }^{131}$ I treatment after 2 and 6 weeks respectively and unchanged with $88 \%$ after 11 weeks.

The effect of $\mathrm{T}_{4}$ treatment and ${ }^{131}$ I-induced hypothyroidism on tumor growth and metastasis formation was compared to that in control mice for two murine cancer models, sarcoma (S1) and fibrosarcoma (T241) (Kumar et al. 1979). $\mathrm{T}_{4}$ treatment led to increased growth rate of tumor implants and rate of metastasis to the popliteal lymph nodes and thymus or lung. Strikingly, hypothyroidism appeared to reverse the effect of $\mathrm{T}_{4}$ with reduced tumor weight as well as reduced metastasis. For these experiments, hypo- and hyperthyroidism were documented by increased or undetectable serum $\mathrm{T}_{4}$ levels. These results were obtained in syngenic murine tumor systems. Similar effects could be observed in xenografts with human cancer cell lines. A prostate cancer cell line, PC-3, grew to significantly larger tumors in untreated mice compared to PTU-treated mice with roughly doubled size after 30 days (Theodossiou \& Schwarzenberger 2000). In a similar experiment, mice were inoculated with PC-3 cells or the poorly differentiated lung carcinoma cell line 201T (Theodossiou et al. 1999). The mice were treated with PTU 3 weeks before inoculation and through the 42 days of the experiment or not treated with PTU. All animals developed tumors, but for both carcinoma cell lines, the tumors in PTU-treated mice were significantly smaller than in untreated mice, demonstrating again that tumor growth is diminished in hypothyroidism.

Experiments with hepatocarcinoma and breast cancer cell lines that lost TR expression and the same cells with
TR $\beta 1$ re-expression (SK/SK-TR $\beta$ and MDA/MDA-TR $\beta$ respectively) injected into nude mice produced similar results regarding tumor growth but different results with regard to metastasis (Martinez-Iglesias et al. 2009). Hypothyroidism reduced tumor volume, tumor proliferation, measured by KI67 index, and increased tumor necrosis in both parental cell lines and the TR $\beta$ expressing cells. Yet, SK cells inoculated into hypothyroid mice always led to tumors that infiltrated adjacent muscle, skin, and vessels, whereas this occurred only in $60-80 \%$ of euthyroid control mice. In $25 \%$ of hypothyroid mice, SK cells metastasized into lung and liver, while in euthyroid mice, no distant metastases were observed.

\section{In vivo effects of $\alpha v \beta 3$ inhibition on tumor growth}

The effect of TH-stimulating cell proliferation and angiogenesis via integrin $\alpha \mathrm{v} \beta 3$ has been demonstrated in vitro for several cell lines. For example, $\mathrm{T}_{4}$ and $\mathrm{T}_{3}$ stimulated proliferation of human non-small cell lung cancer cells (NSCLC, NCI-H1299) in a concentration-dependent manner as measured by PCNA accumulation (Mousa et al. 2012). This effect was inhibited by co-treatment with antibodies against $\alpha v \beta 3$ as well as Tetrac, which confirms that the TH effect is indeed dependent on $\alpha v \beta 3$. Xenografts of the same cell line were implanted in nude mice and treatment with Tetrac resulted in significantly smaller tumor volumes and lower tumor weights as well as lower hemoglobin content as a measure of tumor vascularity (Mousa et al. 2012). The antitumor effect of Tetrac has also been shown in other xenograft models, e.g. medullary thyroid carcinoma, follicular thyroid carcinoma, and RCC (Yalcin et al. 2009, 2010a,b). These observations are very promising because they go beyond merely describing an effect of TH and provide a potential treatment. As the stimulatory effect of $\mathrm{TH}$ on cell proliferation and angiogenesis could clearly be inhibited by Tetrac in vitro, it seems logical to assume that the same mechanisms apply in vivo. But a demonstration that a tumor-stimulating effect of $\mathrm{TH}$ effect observed in vivo, as described earlier, can be blocked by Tetrac treatment has yet to be provided. In a live tumor environment, more signals other than TH (e.g. various growth factors, hypoxia) influence tumor progress, which may in part also be mediated by $\alpha \mathrm{v} \beta 3$ and consequently blocked by Tetrac.

\section{The TR $\beta P V$ mouse model}

TR $\beta$ mutations that prevent $T_{3}$ binding or disturb interaction with corepressors and coactivators lead to

Published by Bioscientifica Ltd 
RTH. In RTH, patients have raised serum TH and raised or inappropriately normal TSH levels. Common clinical features of RTH include goiter, tachycardia, and delayed bone growth with a variable phenotype (Weiss \& Refetoff 2000). The TR $\beta$ PV mouse, a TR $\beta$ knock-in mouse model initially generated as a mouse model of RTH, surprisingly provided more evidence for the involvement of the TRs in carcinogenesis and tumor progression. The TR $\beta P V$ mutation, introduced by homologous recombination, was derived from a patient with severe RTH. A C-insertion at codon 448 (exon 10) produces a frameshift of the carboxyterminal 14 amino acids of TR $\beta 1$. This mutant completely lost $\mathrm{T}_{3}$ binding ability, showed no transactivation activity, and exerted a strong dominant negative effect (Kaneshige et al. 2000). But, interestingly, not all modes of action of TR $\beta$ WT were lost in the TR $\beta$ PV mutant. The TR $\beta P V$ mutant bound significantly stronger to the regulating subunit of PI3K than WT TR $\beta$, leading to stronger activation of PI3K and downstream kinases (mTOR, AKT, and $\mathrm{p} 70^{\mathrm{S} 6 \mathrm{~K}}$ ) (Furuya et al. 2006). Other than the WT TR $\beta$, the TR $\beta$ PV was not able to bind $\mathrm{T}_{3}$. The degree of PI3K activation therefore cannot be modified by $\mathrm{T}_{3}$ levels. Rather, PI3K is constitutively activated by TR $\beta$ PV.

The heterozygous mice, $\mathrm{TR} \beta^{\mathrm{PV} /+}$, reproduced the classical phenotype of RTH with elevated $\mathrm{T}_{4}$ and $\mathrm{TSH}$ levels, enlargement of the thyroid gland, and delayed bone development (Kaneshige et al. 2000). The homozygous $\mathrm{TR} \beta^{\mathrm{PV} / \mathrm{PV}}$ mice showed more severe $\mathrm{RTH}$ and the size of their thyroid gland was several fold increased. The enlargement of the thyroid in the homozygous $\mathrm{TR} \beta^{\mathrm{PV} / \mathrm{PV}}$ mice began at 3 weeks and reached 19- and 36-fold the weight of WT mice at ages 5-7 and $>12$ months respectively (Suzuki et al. 2002). Furthermore, the homozygous mice showed poor survival compared with WT and heterozygous $\mathrm{TR} \beta^{\mathrm{PV} /+}$ mice: median survival was only 12.9 months and at age 14 months only $20 \%$ of the $\mathrm{TR} \beta^{\mathrm{PV} / \mathrm{PV}}$ mice were alive, whereas almost all WT and heterozygous mice survived. Histopathological examination of the thyroid glands showed a neoplastic progression in these $\mathrm{TR} \beta^{\mathrm{PV} / \mathrm{PV}}$ mice, from invasion of the thyroid capsule to development of focal anaplasia and distant metastasis, predominantly to the lung. The $\mathrm{TR} \beta^{\mathrm{PV} / \mathrm{PV}}$ mouse spontaneously developed follicular thyroid cancer. Because the TR $\beta P V$ mutant constitutively activates PI3K and subsequently Akt, phosphorylation status of these kinases was tested in the $\mathrm{TR} \beta^{\mathrm{PV} / \mathrm{PV}}$ mice (Kim et al. 2005). pAKT was markedly increased in both the thyroid tumors and metastases. The importance of PI3K-Akt overactivation in the $\mathrm{TR} \beta^{\mathrm{PV} / \mathrm{PV}}$ mice is highlighted by the fact that treatment with LY294002, a potent PI3K inhibitor, significantly decreased vascular invasion and prevented lung metastases. This led to significantly longer median survival of the LY-treated compared with untreated $\mathrm{TR} \beta^{\mathrm{PV} / \mathrm{PV}}$ mice with $329 \pm 65$ vs $244 \pm 63$ days respectively (Furuya et al. 2007). PI3K is counteracted against by PTEN, which dephosphorylates $\mathrm{PIP}_{3}$. To test whether reducing PTEN further increased tumor growth, mice haplodeficient for PTEN were crossed with the PV mice (TR $\beta^{\mathrm{PV} / \mathrm{PV}}$ Pten $^{+/-}$mice) (Guigon et al. 2009). Indeed, the $\mathrm{TR} \beta^{\mathrm{PV} / \mathrm{PV}}$ Pten $^{+/-}$mice had a significantly shorter median survival time with 5.5 months than either $\mathrm{TR} \beta^{\mathrm{PV} / \mathrm{PV}} \mathrm{Pten}^{+/+}$mice $(10.0$ months) or $\mathrm{TR}^{+/+}$Pten $^{+/-}$mice (14.1 months). Capsular invasion was detectable at earlier age in the $\mathrm{TR}^{\mathrm{PV} / \mathrm{PV}} \mathrm{Pten}^{+/-}$mice compared with $\mathrm{TR} \beta^{\mathrm{PV} / \mathrm{PV}}$ Pten $^{+/+}$mice and anaplasia, vascular invasion and lung metastasis occurred earlier and more frequently in the $\mathrm{TR} \beta^{\mathrm{PV} / \mathrm{PV}} \mathrm{Pten}^{+/-}$mice, which was associated with an increased activation of PI3K.

\section{TR mutants in human cancers}

TR $\alpha$ and $\beta$ mutants have been described in HCC, RCC, and papillary thyroid carcinoma (Lin et al. 1999, Kamiya et al. 2002, Puzianowska-Kuznicka et al. 2002). These mutants arise de novo in carcinomas and often harbor more than one mutation. The main consequences appear to be impaired $\mathrm{T}_{3}$ binding and altered recognition of promoter sequences, leading to regulation of a set of genes distinct from that regulated by the wild-type receptors (Rosen \& Privalsky 2011). This mechanism may contribute to tumor progress, but the clinical relevance is still unclear.

\section{TH and success of tumor therapy}

As TH appear to promote tumor growth, metastasis, and survival in animal models, it seems possible that thyroid function could influence the outcome of tumor therapy, which is defined by exactly these parameters.

For example, an association between TH levels and survival was found for patients with astrocytoma grades III and IV. Twenty-two patients with recurrence after initial surgery and chemo- and/or radiation therapy were treated with tamoxifen (Hercbergs et al. 2003). With the idea that IGF1 inhibits the efficiency of tamoxifen and IGF1 levels are reduced in hypothyroidism, the patients were co-treated with a fixed PTU dose to induce hypothyroidism. Eleven of the 22 patients became hypothyroid. Surprisingly, median survival was significantly longer in

Published by Bioscientifica Ltd. 
the hypothyroid patients (10.1 months) than in the euthyroid patients (3.6 months).

Nelson et al. (2006) analyzed retrospectively whether thyroid function is associated with treatment outcome in head and neck squamous cell cancer. One hundred and fifty-five patients with head and neck cancer were treated with radiation therapy alone or in combination with chemotherapy and/or surgery. Fifty-nine patients developed hypothyroidism with increased TSH levels. Hypothyroidism was most likely a consequence of radiation, but the radiation dose was not different for hypothyroid and euthyroid patients (70 vs $69 \mathrm{~Gy}, \mathrm{NS}$ ). Of the 59 patients who became hypothyroid during the course of treatment and follow-up, 16 had a recurrence (ten before or with diagnosis of hypothyroidism and six after), whereas recurrence was detected in 41 of 96 euthyroid patients. The risk for death or recurrence was significantly lower in hypothyroid patients (HR 0.37, $P<0.001)$. In contrast to the intended induction of hypothyroidism in the glioblastoma patients, the hypothyroid head and neck cancer patients were started on $\mathrm{T}_{4}$, but data on efficacy of $\mathrm{T}_{4}$ supplementation were not available.

\section{Hypothyroidism as a side effect of treatment and treatment outcome}

Development of autoimmune thyroid disease, mostly thyroiditis with hypothyroidism and more seldom autoimmune hyperthyroidism, is a known side effect of interleukin-2 (IL2) treatment. A potential correlation between treatment outcome and thyroid function was noted in the 1990s, when in a small series of 13 patients with RCC or malignant melanoma 6 of 7 eu- or hyperthyroid patients died from progressive disease, but only one of five patients who developed hypothyroidism. Four hypothyroid patients were placed on $\mathrm{T}_{4}$ supplementation (Reid et al. 1991). Similarly, of 15 cancer patients (RCC, malignant melanoma) treated with IL2 and lymphokine-activated killer cells, five of seven hypothyroid patients responded with partial or complete remission, but none of the euthyroid patients (Weijl et al. 1993). Three of the seven hypothyroid patients received $\mathrm{T}_{4}$ substitution.

In the context of thyroid function and cancer treatment outcome, studies with tyrosine kinase inhibitors (TKIs) such as sunitinib are extremely interesting because hypothyroidism is a common side effect of TKIs. Sunitinib is an oral multitargeted TKI with activity against vascular endothelial growth factor receptor, platelet-derived growth factor receptor, KIT, and RET. Sunitinib is also the TKI most frequently associated with hypothyroidism with roughly one-third (range 14-85\%) of patients on sunitinib treatment developing hypothyroidism (Lodish \& Stratakis 2010, Brown 2011). In a recent study using a German pharmacy prescription claims database, 178 of 1295 patients (13.7\%) on sunitinib treatment later received a first prescription for $\mathrm{T}_{4}$ (Feldt et al. 2012). How TKI induce hypothyroidism is not fully understood and several mechanisms have been proposed, for example, reduction of thyroid volume due to atrophy of follicles, degeneration of follicular epithelial cells (Shinohara et al. 2011), and capillary rarefication (Kappers et al. 2011) or inhibition of iodine uptake (Mannavola et al. 2007). Extrathyroidal mechanisms affecting TH metabolism must also be involved because patients with medullary thyroid cancer treated with imatinib, who underwent thyroidectomy and were on $\mathrm{T}_{4}$ replacement therapy, also developed hypothyroidism (de Groot et al. 2007). As one possible explanation, sunitinib appears to increase deiodinase 3 activity (Kappers et al. 2011).

A positive correlation between sunitinib-induced hypothyroidism and progression-free (PFS) or overall survival (OS) of RCC patients was first reported in 2008 (Wolter et al. 2008). Twenty-eight of 40 sunitinib-treated RCC patients became hypothyroid (70\%) and their median PFS was significantly longer than that of euthyroid patients (10.3 vs 3.6 months) as was their OS (18.2 vs 6.6 months). Thirteen hypothyroid patients were supplemented with $\mathrm{T}_{4}$.

In a prospective Italian study, 13 of 22 sunitinibtreated RCC patients (59.1\%) developed hypothyroidism as defined by at least one elevated TSH level (Baldazzi $e t a l$. 2012). Two patients required $T_{4}$ substitution. Again, the hypothyroid patients experienced a longer median PFS (8.55 months) compared with euthyroid patients (7.03 months, $P<0.05)$. In an Austrian study, RCC patients were treated with either sunitinib or sorafenib and subclinical hypothyroidism occurred in 30 patients (36.1\%) (Schmidinger et al. 2011). The rate of objective remission (RECIST criteria) was significantly higher in the hypothyroid patients than in euthyroid patients ( $28.3 \mathrm{vs}$ $3.3 \%$ ) and median survival was longer (not reached vs 13.9 months). $\mathrm{T}_{4}$ replacement was started in 16 patients but normalized TSH in only four, while the other 12 remained hypothyroid. On multivariate analysis, only elevated TSH was an independent predictor of survival.

Development of hypothyroidism was again an independent prognostic parameter in another study of 66 patients with metastatic RCC and sunitinib or sorafenib

Published by Bioscientifica Ltd. 
treatment. Twenty-one patients developed hypothyroidism $(31.8 \%)$, which was associated with a longer median PFS (16.0 vs 6.0 months) (Riesenbeck et al. 2011). Patients with overt hypothyroidism were placed on $\mathrm{T}_{4}$ and the association of hypothyroidism with PFS was not diminished by $\mathrm{T}_{4}$ replacement. Interestingly, a prospective study, for which the investigators chose to supplement all hypothyroid patients, overt and subclinical, found no association between survival and thyroid dysfunction (Sabatier et al. 2012): of 69 patients with RCC, euthyroid at initiation of standard treatment with sunitinib and without disease progression at a 6-month landmark, 45 (65\%) developed hypothyroidism. Patients with elevated TSH were placed on $\mathrm{T}_{4}$ replacement. Mean PFS was not significantly different with 15.9 months for euthyroid patients and 18.9 months for patients with thyroid dysfunction $(P=0.94)$.

Similar effects as for sunitinib were observed for another TKI, cediranib: Speranza et al. (2011) reviewed NCI-sponsored single-agent clinical trials of cediranib and analyzed the response rate for patients with and without hypothyroidism. Hypothyroidism was reported in 168 of 504 (33.3\%) cediranib-treated patients and these had a response rate of $25 \%$, while only $8.6 \%$ of the patients without hypothyroidism showed a response to treatment $(P<0.001)$.

\section{Conclusion and outlook}

Epidemiological data suggest a tumor-promoting effect of $\mathrm{TH}$ as the incidence of some tumors (colon, breast, prostate, and lung cancer) was found to be increased with increasing $\mathrm{TH}$ whereas other tumors, e.g. breast cancer, occur later and are diagnosed in a less advanced stage in patients with hypothyroidism. In tumor transplant rodent models, TH appear to stimulate tumor growth and metastasis, whereas hypothyroidism has opposite effects. Therefore, the results of clinical studies showing that treatment-induced hypothyroidism is associated with a favorable outcome in several cancer types, most prominently in RCC, are immediately comprehensible. In two prospective studies of RCC treated with sunitinib, development of hypothyroidism was an independent predictor of treatment success. Furthermore, in the only study replacing $\mathrm{T}_{4}$ in every RCC patient with elevated TSH and including only patients with normal TSH in the final analysis, no difference in treatment outcome between the patients that developed hypothyroidism and those that remained euthyroid was observed (Sabatier et al. 2012). It is tempting to assume that induction of hypothyroidism is one of the mechanisms through which TKIs slow tumor growth and that correction of hypothyroidism eliminates the survival advantage. There is reasonable concern that substituting these cancer patients with $\mathrm{T}_{4}$ could deprive them of the potential beneficial effects of hypothyroidism (Garfield et al. 2007, 2008).

Yet, one must be cautious because it cannot be ruled out that hypothyroidism is only a surrogate marker of antitumor treatment efficacy due to higher drug levels or different drug metabolism or susceptibility of the immune system in a subset of patients and does not influence tumor growth on its own. There may also be a bias because cancer patients on successful, and therefore continued, treatment are exposed to higher cumulative doses and have more time to develop hypothyroidism than rapidly deteriorating patients. Additionally, a tumor-promoting effect of $\mathrm{TH}$ may only be found in certain types of cancer, such as glioblastoma and RCC, but not for others, e.g. HCC.

Given the results of the tumor implant animal models and the TKI trials in cancer patients, it is of great clinical importance to determine whether and in which types of cancer hypothyroidism can contribute to prolonged survival and should be tolerated or, more provocative, should even be induced. To address these questions, future cancer treatment studies, especially with substances that can induce hypothyroidism, should be designed in a way that allows for an analysis of thyroid function status and its contribution on treatment outcome.

Declaration of interest

The authors declare that there is no conflict of interest that could be perceived as prejudicing the impartiality of the research reported.

\section{Funding}

This work was supported by the Deutsche Forschungsgemeinschaft (grant numbers MO1018/2-1, FU356/3-3) and the IFORES program, Faculty of Medicine, University of Duisburg-Essen.

\section{References}

Baldazzi V, Tassi R, Lapini A, Santomaggio C, Carini M \& Mazzanti R 2012 The impact of sunitinib-induced hypothyroidism on progression-free survival of metastatic renal cancer patients: a prospective singlecenter study. Urologic Oncology 30 704-710. (doi:10.1016/j.urolonc. 2010.07.015)

Bergh JJ, Lin HY, Lansing L, Mohamed SN, Davis FB, Mousa S \& Davis PJ 2005 Integrin $\alpha \mathrm{V} \beta 3$ contains a cell surface receptor site for thyroid hormone that is linked to activation of mitogen-activated protein kinase and induction of angiogenesis. Endocrinology 146 2864-2871. (doi:10.1210/en.2005-0102) http://erc.endocrinology-journals.org DOI: $10.1530 /$ ERC-12-0219
(C) 2013 Society for Endocrinology Printed in Great Britain
Published by Bioscientifica Ltd 
Bochukova E, Schoenmakers N, Agostini M, Schoenmakers E, Rajanayagam O, Keogh JM, Henning E, Reinemund J, Gevers E, Sarri M et al. 2012 A mutation in the thyroid hormone receptor $\alpha$ gene. New England Journal of Medicine 366 243-249. (doi:10.1056/NEJMoa1110296)

Brown RL 2011 Tyrosine kinase inhibitor-induced hypothyroidism: incidence, etiology, and management. Targeted Oncology 6 217-226. (doi:10.1007/s11523-011-0197-2)

Cao X, Kambe F, Moeller LC, Refetoff S \& Seo H 2005 Thyroid hormone induces rapid activation of Akt/protein kinase B-mammalian target of rapamycin-p70S6K cascade through phosphatidylinositol 3-kinase in human fibroblasts. Molecular Endocrinology 19 102-112. (doi:10.1210/ me.2004-0093)

Cao X, Kambe F, Yamauchi M \& Seo H 2009 Thyroid-hormone-dependent activation of the phosphoinositide 3-kinase/Akt cascade requires Src and enhances neuronal survival. Biochemical Journal 424 201-209. (doi:10.1042/BJ20090643)

Chalhoub N \& Baker SJ 2009 PTEN and the PI3-kinase pathway in cancer. Annual Review of Pathology 4 127-150. (doi:10.1146/annurev.pathol.4. 110807.092311)

Chan IH \& Privalsky ML 2009 Isoform-specific transcriptional activity of overlapping target genes that respond to thyroid hormone receptors $\alpha 1$ and $\beta 1$. Molecular Endocrinology 23 1758-1775. (doi:10.1210/me.20090025)

Cheng SY, Leonard JL \& Davis PJ 2010 Molecular aspects of thyroid hormone actions. Endocrine Reviews 31 139-170. (doi:10.1210/er.20090007)

Chiamolera MI, Sidhaye AR, Matsumoto S, He Q, Hashimoto K, Ortiga-Carvalho TM \& Wondisford FE 2012 Fundamentally distinct roles of thyroid hormone receptor isoforms in a thyrotroph cell line are due to differential DNA binding. Molecular Endocrinology 26 926-939. (doi:10.1210/me.2011-1290)

Cristofanilli M, Yamamura Y, Kau S-W, Bevers T, Strom S, Patangan M, Hsu L, Krishnamurthy S, Theriault RL \& Hortobagyi GN 2005 Thyroid hormone and breast carcinoma. Cancer 103 1122-1128. (doi:10.1002/ cncr.20881)

Davis FB 2004 Proangiogenic action of thyroid hormone is fibroblast growth factor-dependent and is initiated at the cell surface. Circulation Research 94 1500-1506. (doi:10.1161/01.RES.0000130784.90237.4a)

Davis PJ, Davis FB, Mousa SA, Luidens MK \& Lin HY 2011 Membrane receptor for thyroid hormone: physiologic and pharmacologic implications. Annual Review of Pharmacology and Toxicology 51 99-115. (doi:10.1146/annurev-pharmtox-010510-100512)

Feldt S, Schussel K, Quinzler R, Franzmann A, Czeche S, Ludwig WD \& Schulz M 2012 Incidence of thyroid hormone therapy in patients treated with sunitinib or sorafenib: a cohort study. European Journal of Cancer 48 974-981. (doi:10.1016/j.ejca.2012.01.036)

Ferrara AM, Onigata K, Ercan O, Woodhead H, Weiss RE \& Refetoff S 2012 Homozygous thyroid hormone receptor $\beta$-gene mutations in resistance to thyroid hormone: three new cases and review of the literature. Journal of Clinical Endocrinology and Metabolism 97 1328-1336. (doi:10.1210/jc.2011-2642)

Freindorf M, Furlani TR, Kong J, Cody V, Davis FB \& Davis PJ 2012 Combined $\mathrm{QM} / \mathrm{MM}$ study of thyroid and steroid hormone analogue interactions with $\alpha \mathrm{v} \beta 3$ integrin. Journal of Biomedicine \& Biotechnology 2012 959057. (doi:10.1155/2012/959057)

Fung KM 2006 Increased expression of type 23 -hydroxysteroid dehydrogenase/type 517 -hydroxysteroid dehydrogenase (AKR1C3) and its relationship with androgen receptor in prostate carcinoma. Endocrine-Related Cancer 13 169-180. (doi:10.1677/erc.1.01048)

Furuya F, Hanover JA \& Cheng SY 2006 Activation of phosphatidylinositol 3-kinase signaling by a mutant thyroid hormone $\beta$ receptor. PNAS 103 1780-1785. (doi:10.1073/pnas.0510849103)

Furuya F, Lu C, Willingham MC \& Cheng SY 2007 Inhibition of phosphatidylinositol 3-kinase delays tumor progression and blocks metastatic spread in a mouse model of thyroid cancer. Carcinogenesis $\mathbf{2 8}$ 2451-2458. (doi:10.1093/carcin/bgm174)
Garfield DH, Hercbergs A \& Davis PJ 2007 Re: hypothyroidism in patients with metastatic renal cell carcinoma treated with sunitinib. Journal of the National Cancer Institute 99 975-976 author reply 976-977. (doi:10.1093/jnci/djm008)

Garfield DH, Wolter P, Schoffski P, Hercbergs A \& Davis P 2008 Documentation of thyroid function in clinical studies with sunitinib: why does it matter? Journal of Clinical Oncology 26 5131-5132 author reply 5132-5133. (doi:10.1200/JCO.2008.18.8680)

de Groot JW, Zonnenberg BA, van Ufford-Mannesse PQ, de Vries MM, Links TP, Lips CJ \& Voest EE 2007 A phase II trial of imatinib therapy for metastatic medullary thyroid carcinoma. Journal of Clinical Endocrinology and Metabolism 92 3466-3469. (doi:10.1210/jc.2007-0649)

Guigon CJ, Zhao L, Willingham MC \& Cheng SY 2009 PTEN deficiency accelerates tumour progression in a mouse model of thyroid cancer. Oncogene 28 509-517. (doi:10.1038/onc.2008.407)

Hassan MM, Kaseb A, Li D, Patt YZ, Vauthey J-N, Thomas MB, Curley SA, Spitz MR, Sherman SI, Abdalla EK et al. 2009 Association between hypothyroidism and hepatocellular carcinoma: a case-control study in the United States. Hepatology 49 1563-1570. (doi:10.1002/hep.22793)

Hellevik AI, Asvold BO, Bjoro T, Romundstad PR, Nilsen TIL \& Vatten LJ 2009 Thyroid function and cancer risk: a prospective population study. Cancer Epidemiology, Biomarkers \& Prevention 18 570-574. (doi:10.1158/ 1055-9965.EPI-08-0911)

Hercbergs AA, Goyal LK, Suh JH, Lee S, Reddy CA, Cohen BH, Stevens GH, Reddy SK, Peereboom DM, Elson PJ et al. 2003 Propylthiouracil-induced chemical hypothyroidism with high-dose tamoxifen prolongs survival in recurrent high grade glioma: a phase I/II study. Anticancer Research $\mathbf{2 3}$ $617-626$.

Hiroi Y, Kim HH, Ying H, Furuya F, Huang Z, Simoncini T, Noma K, Ueki K, Nguyen NH, Scanlan TS et al. 2006 Rapid nongenomic actions of thyroid hormone. PNAS 103 14104-14109. (doi:10.1073/pnas. $0601600103)$

Kamiya Y, Puzianowska-Kuznicka M, McPhie P, Nauman J, Cheng SY \& Nauman A 2002 Expression of mutant thyroid hormone nuclear receptors is associated with human renal clear cell carcinoma. Carcinogenesis 23 25-33. (doi:10.1093/carcin/23.1.25)

Kaneshige M, Kaneshige K, Zhu X, Dace A, Garrett L, Carter TA, Kazlauskaite R, Pankratz DG, Wynshaw-Boris A, Refetoff S et al. 2000 Mice with a targeted mutation in the thyroid hormone $\beta$ receptor gene exhibit impaired growth and resistance to thyroid hormone. PNAS 97 13209-13214. (doi:10.1073/pnas.230285997)

Kappers MH, van Esch JH, Smedts FM, de Krijger RR, Eechoute K, Mathijssen RH, Sleijfer S, Leijten F, Danser AH, van den Meiracker AH et al. 2011 Sunitinib-induced hypothyroidism is due to induction of type 3 deiodinase activity and thyroidal capillary regression. Journal of Clinical Endocrinology and Metabolism 96 3087-3094. (doi:10.1210/jc. 2011-1172)

Kim CS, Vasko VV, Kato Y, Kruhlak M, Saji M, Cheng SY \& Ringel MD 2005 AKT activation promotes metastasis in a mouse model of follicular thyroid carcinoma. Endocrinology 146 4456-4463. (doi:10.1210/en. 2005-0172)

Kimbro KS \& Simons JW 2006 Hypoxia-inducible factor-1 in human breast and prostate cancer. Endocrine-Related Cancer 13 739-749. (doi:10.1677/ erc.1.00728)

Ko AH, Wang F \& Holly EA 2007 Pancreatic cancer and medical history in a population-based case-control study in the San Francisco Bay Area, California. Cancer Causes \& Control 18 809-819. (doi:10.1007/s10552007-9024-6)

Kumar MS, Chiang T \& Deodhar SD 1979 Enhancing effect of thyroxine on tumor growth and metastases in syngeneic mouse tumor systems. Cancer Research 39 3515-3518.

Lehrer S, Diamond EJ, Bajwa AM, Kornreich R, Stagger S, Stone NN, Droller MJ \& Stock RG 2001 Association between serum triiodothyronine $\left(\mathrm{T}_{3}\right)$ level and risk of disease recurrence in men with localized prostate cancer. Prostate Cancer and Prostatic Diseases 4 232-234. (doi:10.1038/sj.pcan.4500542) 
Lehrer S, Diamond EJ, Stone NN, Droller MJ \& Stock RG 2002 Serum triiodothyronine is increased in men with prostate cancer and benign prostatic hyperplasia. Journal of Urology 168 2431-2433. (doi:10.1016/ S0022-5347(05)64161-4)

Lei J, Mariash CN \& Ingbar DH 2004 3,3',5-Triiodo-L-thyronine up-regulation of $\mathrm{Na}$,K-ATPase activity and cell surface expression in alveolar epithelial cells is Src kinase- and phosphoinositide 3-kinase-dependent. Journal of Biological Chemistry 279 47589-47600. (doi:10.1074/jbc.M405497200)

Lin KH, Shieh HY, Chen SL \& Hsu HC 1999 Expression of mutant thyroid hormone nuclear receptors in human hepatocellular carcinoma cells. Molecular Carcinogenesis 26 53-61. (doi:10.1002/(SICI)1098-2744 (199909)26:1 < 53::AID-MC7 > 3.0.CO;2-Z)

Lin HY, Sun M, Tang HY, Lin C, Luidens MK, Mousa SA, Incerpi S, Drusano GL, Davis FB \& Davis PJ 2009 L-thyroxine vs. 3,5,3'-triiodo-L-thyronine and cell proliferation: activation of mitogen-activated protein kinase and phosphatidylinositol 3-kinase. American Journal of Physiology. Cell Physiology 296 C980-C991. (doi:10.1152/ajpcell.00305.2008)

Lodish MB \& Stratakis CA 2010 Endocrine side effects of broad-acting kinase inhibitors. Endocrine-Related Cancer 17 R233-R244. (doi:10.1677/ERC-10-0082)

Mannavola D, Coco P, Vannucchi G, Bertuelli R, Carletto M, Casali PG, Beck-Peccoz P \& Fugazzola L 2007 A novel tyrosine-kinase selective inhibitor, sunitinib, induces transient hypothyroidism by blocking iodine uptake. Journal of Clinical Endocrinology and Metabolism 92 3531-3534. (doi:10.1210/jc.2007-0586)

Martinez-Iglesias O, Garcia-Silva S, Regadera J \& Aranda A 2009 Hypothyroidism enhances tumor invasiveness and metastasis development. PLoS ONE 4 e6428. (doi:10.1371/journal.pone.0006428)

Mishkin SY, Pollack R, Yalovsky MA, Morris HP \& Mishkin S 1981 Inhibition of local and metastatic hepatoma growth and prolongation of survival after induction of hypothyroidism. Cancer Research $\mathbf{4 1}$ 3040-3045.

Moeller LC, Dumitrescu AM \& Refetoff S 2005a Cytosolic action of thyroid hormone leads to induction of hypoxia-inducible factor- $1 \alpha$ and glycolytic genes. Molecular Endocrinology 19 2955-2963. (doi:10.1210/ me.2004-0542)

Moeller LC, Dumitrescu AM, Walker RL, Meltzer PS \& Refetoff S 2005b Thyroid hormone responsive genes in cultured human fibroblasts. Journal of Clinical Endocrinology and Metabolism 90 936-943. (doi:10.1210/jc.2004-1768)

Mondul AM, Weinstein SJ, Bosworth T, Remaley AT, Virtamo J \& Albanes D 2012 Circulating thyroxine, thyroid-stimulating hormone, and hypothyroid status and the risk of prostate cancer. PLOS ONE 7 e47730. (doi:10.1371/journal.pone.0047730)

Mousa SA, Yalcin M, Bharali DJ, Meng R, Tang HY, Lin HY, Davis FB \& Davis PJ 2012 Tetraiodothyroacetic acid and its nanoformulation inhibit thyroid hormone stimulation of non-small cell lung cancer cells in vitro and its growth in xenografts. Lung Cancer 76 39-45. (doi:10.1016/j.lungcan.2011.10.003)

van Mullem A, van Heerebeek R, Chrysis D, Visser E, Medici M, Andrikoula M, Tsatsoulis A, Peeters R \& Visser TJ 2012 Clinical phenotype and mutant TR $\alpha 1$. New England Journal of Medicine 366 1451-1453. (doi:10.1056/NEJMc1113940)

Nelson M, Hercbergs A, Rybicki L \& Strome M 2006 Association between development of hypothyroidism and improved survival in patients with head and neck cancer. Archives of Otolaryngology-Head \& Neck Surgery 132 1041-1046. (doi:10.1001/archotol.132.10.1041)

Ness RB, Grisso JA, Cottreau C, Klapper J, Vergona R, Wheeler JE, Morgan M \& Schlesselman JJ 2000 Factors related to inflammation of the ovarian epithelium and risk of ovarian cancer. Epidemiology 11 111-117. (doi:10.1097/00001648-200003000-00006)

Penning TM \& Byrns MC 2009 Steroid hormone transforming aldo-keto reductases and cancer. Annals of the New York Academy of Sciences 1155 33-42. (doi:10.1111/j.1749-6632.2009.03700.x)
Puzianowska-Kuznicka M, Krystyniak A, Madej A, Cheng SY \& Nauman J 2002 Functionally impaired TR mutants are present in thyroid papillary cancer. Journal of Clinical Endocrinology and Metabolism 87 1120-1128. (doi:10.1210/jc.87.3.1120)

Reddy A, Dash C, Leerapun A, Mettler TA, Stadheim LM, Lazaridis KN, Roberts RO \& Roberts LR 2007 Hypothyroidism: a possible risk factor for liver cancer in patients with no known underlying cause of liver disease. Clinical Gastroenterology and Hepatology 5 118-123. (doi:10.1016/j.cgh.2006.07.011)

Refetoff S \& Dumitrescu AM 2007 Syndromes of reduced sensitivity to thyroid hormone: genetic defects in hormone receptors, cell transporters and deiodination. Best Practice \& Research. Clinical Endocrinology \& Metabolism 21 277-305. (doi:10.1016/j.beem.2007.03.005)

Reid I, Sharpe I, McDevitt J, Maxwell W, Emmons R, Tanner WA \& Monson JR 1991 Thyroid dysfunction can predict response to immunotherapy with interleukin-2 and interferon-2 $\alpha$. British Journal of Cancer 64 915-918. (doi:10.1038/bjc.1991.426)

Riesenbeck LM, Bierer S, Hoffmeister I, Kopke T, Papavassilis P, Hertle L, Thielen B \& Herrmann E 2011 Hypothyroidism correlates with a better prognosis in metastatic renal cancer patients treated with sorafenib or sunitinib. World Journal of Urology 29 807-813. (doi:10.1007/s00345010-0627-2)

Rosen MD \& Privalsky ML 2011 Thyroid hormone receptor mutations in cancer and resistance to thyroid hormone: perspective and prognosis. Journal of Thyroid Research 2011 361304. (doi:10.4061/2011/361304)

Sabatier R, Eymard JC, Walz J, Deville JL, Narbonne H, Boher JM, Salem N, Marcy M, Brunelle S, Viens P et al. 2012 Could thyroid dysfunction influence outcome in sunitinib-treated metastatic renal cell carcinoma? Annals of Oncology 23 714-721. (doi:10.1093/annonc/mdr275)

Schmidinger M, Vogl UM, Bojic M, Lamm W, Heinzl H, Haitel A, Clodi M, Kramer G \& Zielinski CC 2011 Hypothyroidism in patients with renal cell carcinoma: blessing or curse? Cancer 117 534-544. (doi:10.1002/ cncr.25422)

Semenza GL 2009 Defining the role of hypoxia-inducible factor 1 in cancer biology and therapeutics. Oncogene 29 625-634. (doi:10.1038/ onc.2009.441)

Shinohara N, Takahashi M, Kamishima T, Ikushima H, Otsuka N, Ishizu A, Shimizu C, Kanayama H \& Nonomura K 2011 The incidence and mechanism of sunitinib-induced thyroid atrophy in patients with metastatic renal cell carcinoma. British Journal of Cancer 104 241-247. (doi:10.1038/sj.bjc.6606029)

Shoemaker JP, Bradley RL \& Hoffman RV 1976 Increased survival and inhibition of mammary tumors in hypothyroid mice. Journal of Surgical Research 21 151-154. (doi:10.1016/0022-4804(76)90151-7)

Simoncini T, Hafezi-Moghadam A, Brazil DP, Ley K, Chin WW \& Liao JK 2000 Interaction of oestrogen receptor with the regulatory subunit of phosphatidylinositol-3-OH kinase. Nature 407 538-541. (doi:10.1038/ 35035131)

Speranza G, Rubinstein L, Ivy SP \& Harris PJ 2011 Correlation between adverse event reports of hypothyroidism and clinical response in patients treated with vascular endothelial growth factor receptor inhibitors (VEGFR-I). Journal of Clinical Oncology 29 (Supplement: ASCO Meeting Abstracts Part 1) abstract 2602.

Suzuki H, Willingham MC \& Cheng SY 2002 Mice with a mutation in the thyroid hormone receptor $\beta$ gene spontaneously develop thyroid carcinoma: a mouse model of thyroid carcinogenesis. Thyroid $\mathbf{1 2}$ 963-969. (doi:10.1089/105072502320908295)

Theodossiou C \& Schwarzenberger P 2000 Propylthiouracil reduces xenograft tumor growth in an athymic nude mouse prostate cancer model. American Journal of the Medical Sciences 319 96-99. (doi:10.1097/ 00000441-200002000-00005)

Theodossiou C, Skrepnik N, Robert EG, Prasad C, Axelrad TW, Schapira DV \& Hunt JD 1999 Propylthiouracil-induced hypothyroidism reduces xenograft tumor growth in athymic nude mice. Cancer 86 1596-1601. (doi:10.1002/(SICI)1097-0142(19991015)86:8 < 1596::AID-CNCR30> 3.0.CO;2-C) 
Tosovic A, Bondeson AG, Bondeson L, Ericsson UB, Malm J \& Manjer J 2010 Prospectively measured triiodothyronine levels are positively associated with breast cancer risk in postmenopausal women. Breast Cancer Research 12 R33. (doi:10.1186/bcr2587)

Weijl NI, Van der Harst D, Brand A, Kooy Y, Van Luxemburg S, Schroder J, Lentjes E, Van Rood JJ, Cleton FJ \& Osanto S 1993 Hypothyroidism during immunotherapy with interleukin-2 is associated with antithyroid antibodies and response to treatment. Journal of Clinical Oncology 11 1376-1383.

Weiss RE \& Refetoff S 2000 Resistance to thyroid hormone. Reviews in Endocrine \& Metabolic Disorders 1 97-108. (doi:10.1023/ A:1010072605757)

Wolter P, Stefan C, Decallonne B, Dumez H, Fieuws S, Wildiers H, Clement P, Debaere D, Van Oosterom A \& Schöffski P 2008 Evaluation of thyroid dysfunction as a candidate surrogate marker for efficacy of sunitinib in patients (pts) with advanced renal cell cancer (RCC). Journal of Clinical Oncology 26 (Supplement: ASCO Meeting Abstracts).

Yalcin M, Bharali DJ, Lansing L, Dyskin E, Mousa SS, Hercbergs A, Davis FB, Davis PJ \& Mousa SA 2009 Tetraidothyroacetic acid (Tetrac) and Tetrac nanoparticles inhibit growth of human renal cell carcinoma xenografts. Anticancer Research 29 3825-3831.

Yalcin M, Bharali DJ, Dyskin E, Dier E, Lansing L, Mousa SS, Davis FB, Davis PJ \& Mousa SA 2010a Tetraiodothyroacetic acid and tetraiodothyroacetic acid nanoparticle effectively inhibit the growth of human follicular thyroid cell carcinoma. Thyroid 20 281-286. (doi:10.1089/thy.2009.0249)

Yalcin M, Dyskin E, Lansing L, Bharali DJ, Mousa SS, Bridoux A, Hercbergs AH, Lin HY, Davis FB, Glinsky GV et al. $2010 b$ Tetraiodothyroacetic acid (Tetrac) and nanoparticulate Tetrac arrest growth of medullary carcinoma of the thyroid. Journal of Clinical Endocrinology and Metabolism 95 1972-1980. (doi:10.1210/jc.2009-1926)

Yen PM 2001 Physiological and molecular basis of thyroid hormone action. Physiological Reviews 81 1097-1142.

Yen PM, Feng X, Flamant F, Chen Y, Walker RL, Weiss RE, Chassande O, Samarut J, Refetoff S \& Meltzer PS 2003 Effects of ligand and thyroid hormone receptor isoforms on hepatic gene expression profiles of thyroid hormone receptor knockout mice. EMBO Reports 4 581-587. (doi:10.1038/sj.embor.embor862)

Received in final form 20 December 2012

Accepted 3 January 2013

Made available online as an Accepted Preprint

14 January 2013 http://erc.endocrinology-journals.org DOI: 10.1530/ERC-12-0219
(C) 2013 Society for Endocrinology Printed in Great Britain
Published by Bioscientifica Ltd. 